Piotr Dela

ORCID:0000-0003-3643-3759

\title{
Elementy propagandy w życiu publicznym
}

\section{SŁOWA KLUCZOWE:}

propaganda, dezinformacja, bezpieczeństwo informacyjne

\section{Wprowadzenie}

Obserwując współczesne wydarzenia, można wyciągnąć wniosek, że cokolwiek stanie się na świecie, natychmiast jesteśmy o tym poinformowani. Niemniej jednak informacja, która dociera do społeczeństwa, nie jest dokładnym odzwierciedleniem rzeczywistości, lecz jedynie jej interpretacją, która wykorzystywana jest do stworzenia odpowiedniej reakcji jej odbiorców. Informacja, bo ona ma tutaj największe znaczenie, to narzędzie polityki wykorzystywane zarówno na poziomie lokalnym (państwa), jak i globalnym (międzynarodowym). Przekazy informacyjne, zarówno współczesne jak i na przestrzeni wieków, są elementem szeroko pojmowanej walki politycznej, walki informacyjnej (w ujęciu militarnym i niemilitarnym), a także propagandy stanowiącej ich nieodzowny element. Niniejszy tekst skupia się na najważniejszych aspektach współczesnej propagandy. Jej oblicze jest niezwykle zmienne i ma odzwierciedlenie w środowisku, w którym jest ona realizowana. Integralnymi częściami tego środowiska są przestrzeń bezpieczeństwa państwa, cyberprzestrzeń i przestrzeń informacyjna. Oczywiście przestrzenie te są ze sobą ściśle powiązane i wywieraja na siebie wzajemny wpływ. Głównym celem opracowania jest zidentyfikowanie oblicza współczesnej propagandy i jej znaczenia w życiu publicznym. Realizuje ona bowiem cele polityczne, 
prowadzona jest zgodnie z pewnymi utartymi technikami i etapami w środowisku, w którym znaczącą rolę odgrywają media publiczne i komercyjne, ale także z coraz większą rolą cyberprzestrzeni, ze szczególnym uwzględnieniem mediów społecznościowych. Realizacja powyższego celu wymaga w pierwszej kolejności identyfikacji podstawowych terminów, takich jak informacja, przestrzeń bezpieczeństwa państwa, przestrzeń informacyjna i cyberprzestrzeń, bezpieczeństwo informacyjne, walka informacyjna, dezinformacja i propaganda. Następnie przedstawione zostaną podstawowe rodzaje propagandy, techniki, przy pomocy których jest ona realizowana, oraz przebieg klasycznej kampanii informacyjnej (propagandowej).

\section{Informacja - uwarunkowania środowiskowe}

Współcześnie istnieje szereg różnorodnych definicji oraz ujęć terminu informacja. Przez wielu teoretyków jest ona uważana za pojęcie pierwotne, niedające się zdefiniować. Ponadto funkcjonowanie informacji w różnorodnym środowisku (politycznym, fizycznym, matematycznym, ekonomicznym itp.) spowodowało, iz do tej pory nie doczekała się ona jednoznacznej definicji wyrażającej jej istotę. Czzéść autorów rezygnuje z jej definiowania, poprzestając na intuicyjnym i potocznym jej rozumieniu. Niemniej jednak należy zauważyć, że samo słowo informacja wywodzi się z łacińskiego słowa informatio, co oznacza wyobrażenie, wyjaśnienie, zawiadomienie. Interesujący zbiór definicji terminu informacja przedstawia w jednej ze swoich publikacji Wiesław Flakiewicz ${ }^{1}$. Przytacza on najpopularniejsze definicje tego pojęcia:

- Informacja to komunikacja, łączność, w wyniku której likwiduje się nieokreśloność (Claude E. Shannon).

- Informacja jest nazwą treści zaczerpniętej ze świata zewnętrznego, nie jest więc ani materią, ani energią (Norbert Wiener).

- Informacja jest to czynnik sterujący strumieniami zasileń, wykorzystywany w organizmach żywych lub maszynach do bardziej sprawnego, efektywnego i celowego działania (Edward Kowalczyk).

- Informacja jest to treść przekazywanych od nadawcy do odbiorcy wiadomości, będąca opisem, poleceniem, zakazem, nakazem lub zleceniem (Janusz Gościński).

1 W. Flakiewicz, Podejmowanie decyzji kierowniczych, Warszawa 1973, s. 38. 
- Jest to przekazywanie wiedzy do odbiorcy informacji, umożliwiające ze względu na jej wartość zmniejszenie niepewności działania odbiorcy informacji (Russell L. Ackoff).

- Informacja jest to wiedza przekazywana przez innych ludzi bądź uzyskiwana przez studia, obserwacje, badania (A. Webster).

Także Leopold Ciborowski w swojej książce Walka informacyjna, podejmując się analizy pojęcia informacja, powołał się na kilkanaście definicji stworzonych przez naukowców z dziedziny cybernetyki i fizyki. Podsumowując cytowane definicje zauważył on, że informacja jest niejako bodźcem oddziałującym na układ recepcyjny człowieka, powodującym w jego wyobraźni wytworzenie przedmiotu myślowego, który odzwierciedla obraz rzeczy materialnej i abstrakcyjnej oraz w jego przekazie kojarzy się z tym bodźcem. Ponadto Ciborowski uważa, że związek między człowiekiem i informacją jest nierozerwalny: „Tak jak foton nie może istnieć bez pędu, tak informacja nie może istnieć bez umysłu ludzkiego. Tylko ten organ natury ludzkiej dostosowany jest do nieskończonego przetwarzania transformowanych doznań recepcyjnych w wyobrażenia informacyjne. [...] każda informacja jest szczególną formą sygnału, która oprócz wspólnych cech wyróżnialności, właściwych dla sygnału i informacji, posiada jeszcze tę właściwość, że inspiruje umysł ludzki do tworzenia pewnej wyobraźni”2.

Interesującą definicję informacji przedstawił także Piotr Sienkiewicz, dla którego informacja to „zbiór faktów, zdarzeń, cech, obiektów ujęty w takiej formie, że pozwala odbiorcy ustosunkować się do zaistniałej sytuacji i podjąć odpowiednie działania umysłowe lub fizyczne"3.

W literaturze można także zauważyć, że sama informacja ma wymiar strukturalny. Podejście strukturalne mówi o tym, że w każdej strukturze zawiera się informacja warunkująca zachowanie odpowiedniej (właściwej) formy tej struktury, odnosząca się do celów, wartości oraz sposobów funkcjonowania danej struktury (organizacji, społeczności).

Zapoznając się z przedstawionymi na rysunku 1 elementami - zaczynając od dołu do góry, czyli od surowych danych (ich fizycznego aspektu - fizycznej postaci), przez zorganizowane informacje (dane mogące być zinterpretowane przy pomocy aparatu poznawczego) i informacje przetworzone, aż do poziomu wiedzy (zinterpretowane i przyswojone) oraz najwyższego poziomu informacji, czyli mądrości (bazującej na wiedzy, wykształceniu i doświadczeniu) - należy zauważyć, że dane, aby mogły

2 L. Ciborowski, Walka informacyjna, Toruń 1999, s. 59.

3 P. Sienkiewicz, Systemy kierowania, Warszawa 1989, s. 128. 
stać się informacją, muszą zostać przetworzone, a do tego niezbędna jest wiedza. Dwa najniższe szczeble odnoszą się do podejścia przetwarzania, a dwa górne do podejścia strukturalnego. Szczeble te nie są od siebie zależne, ponieważ większa liczba danych nie oznacza większej liczby informacji. Podobnie większa liczba informacji nie jest tożsama z większą wiedzą, a czasami wręcz przeciwnie - zbyt wielka liczba informacji ogranicza wiedzę, a nawet paraliżuje jej działania.

\section{Rysunek 1. Piramida informacyjna}

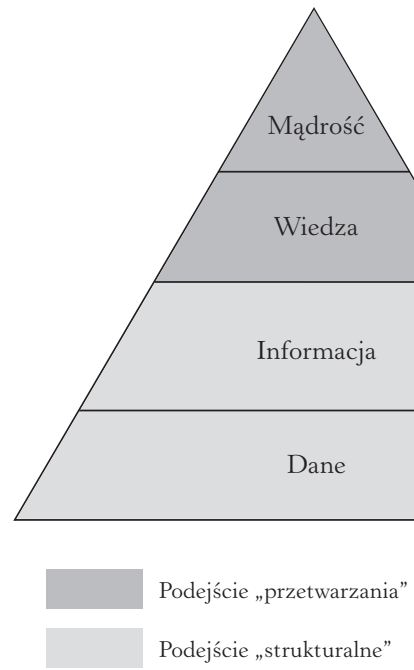

Źródło: P. Sienkiewicz, Wiek informacji, Warszawa 2000.

Informacja jest podstawą do budowania każdego systemu wiedzy, warunkuje sukces. Możemy zauważyć, że informacja nabiera ogromnego znaczenia w każdej dziedzinie działalności człowieka, a w szczególności w takich sferach, jak: społeczna, gospodarcza, zarządzania, polityczna, kulturowo-religijna, bezpieczeństwa.

Przedstawione powyżej rozważania uprawniają do stwierdzenia, że informacja jest czymś więcej niż tylko wiadomością, znakiem lub inną formą komunikowania. W swojej istocie jest zarówno opisem rzeczywistości, jak i odzwierciedleniem stanu systemu oraz jego elementów, który może podlegać procesom pozyskiwania, przetwarzania, gromadzenia lub dystrybucji. Uwarunkowania te są niezwykle istotne z punktu widzenia działań, jakie podejmowane są w trakcie kampanii propagandowych. Informacja bowiem jest odbiciem obrazu obserwowanej rzeczywistości, która nie musi być odzwierciedleniem prawdy lub stanu faktycznego. $\mathrm{Na}$ bazie 
tego odbicia budowana jest wiedza, która jest równocześnie pochodną wielu różnorodnych czynników, takich jak: wykształcenie, doświadczenie, przekonanie obserwatora itp. Wiedza, najogólniej rzecz ujmując, to ogół wiarygodnych informacji o rzeczywistości wraz z umiejętnością ich wykorzystywania 4 . Przymiotnik „wiarygodnych” jest gwarantem poprawności interpretacji informacji i odpowiedniego ustosunkowania się do niej. Jeżeli uzyskany obraz rzeczywistości odbiegać będzie w jakimś stopniu od prawdy, jeżeli uzyskana informacja nie będzie cechowała się wiarygodnością, to stworzona na jej podstawie wiedza nie będzie gwarantowała prawidłowej interpretacji rzeczywistości. W takie podejście do przekazu informacji wpisuje się propaganda.

Istotnym terminem związanym bezpośrednio z informacją jest przestrzeń informacyjna, której rozwój nierozerwalnie jest związany z rozwojem ludzkości. Pierwotnie przestrzeń ta obejmowała swym zasięgiem lokalne społeczności, takie jak plemiona. Z upływem czasu obszar jej oddziaływania zwiększał się wraz z rozwojem struktur społecznych i wykorzystywanych narzędzi komunikacyjnych. Narzędzia te jednak miały najczęściej ograniczenia związane z zasięgiem i czasem przekazywania informacji. Dopiero rozwój telekomunikacji, informatyki i teleinformatyki spowodował diametralne zmiany w przestrzeni informacyjnej i nie może być ona dziś kojarzona z jakąkolwiek społecznością lokalną. Obejmuje swym zasięgiem praktycznie całą powierzchnię kuli ziemskiej przy jednoczesnym skróceniu czasu przesyłu informacji do minimum. $\mathrm{Na}$ rysunku 2 przedstawiono drzewo rozwoju domen komunikacyjnych, które były i są istotnym elementem każdej kampanii propagandowej. Należy zwrócić uwagę, że najwyżej w hierarchii znajduje się cyberprzestrzeń, która stała się najważniejszym elementem informacyjnego oddziaływania we współczesnym świecie.

Najogólniej rzecz ujmując, współczesna przestrzeń informacyjna jest złożoną całością interakcji, wartości i funkcji łączących światy realne, wirtualne, indywidualne, społeczne, przeszłe, obecne i przyszłe ${ }^{5}$. To nie tylko swoiste narzędzie wymiany informacji pomiędzy elementami składowymi systemu bezpieczeństwa podmiotu, ale również odbicie ich wzajemnych powiązań i relacjí6.

4 Hasło: Wiedza, [w:] Encyklopedia PWN, http://encyklopedia.pwn.pl/haslo/3995573/ wiedza.html (dostęp: 22.12.2018).

5 Por. S. Jaskuła, Informacyjna przestrzeń tożsamości, Warszawa 2010, s. 1.

6 Por. R. Kwećka, Strategia bezpieczeństwa informacyjnego państwa, Warszawa 2014, s. 25. 
Rysunek 2. Studium rozwoju domen komunikacyjnych

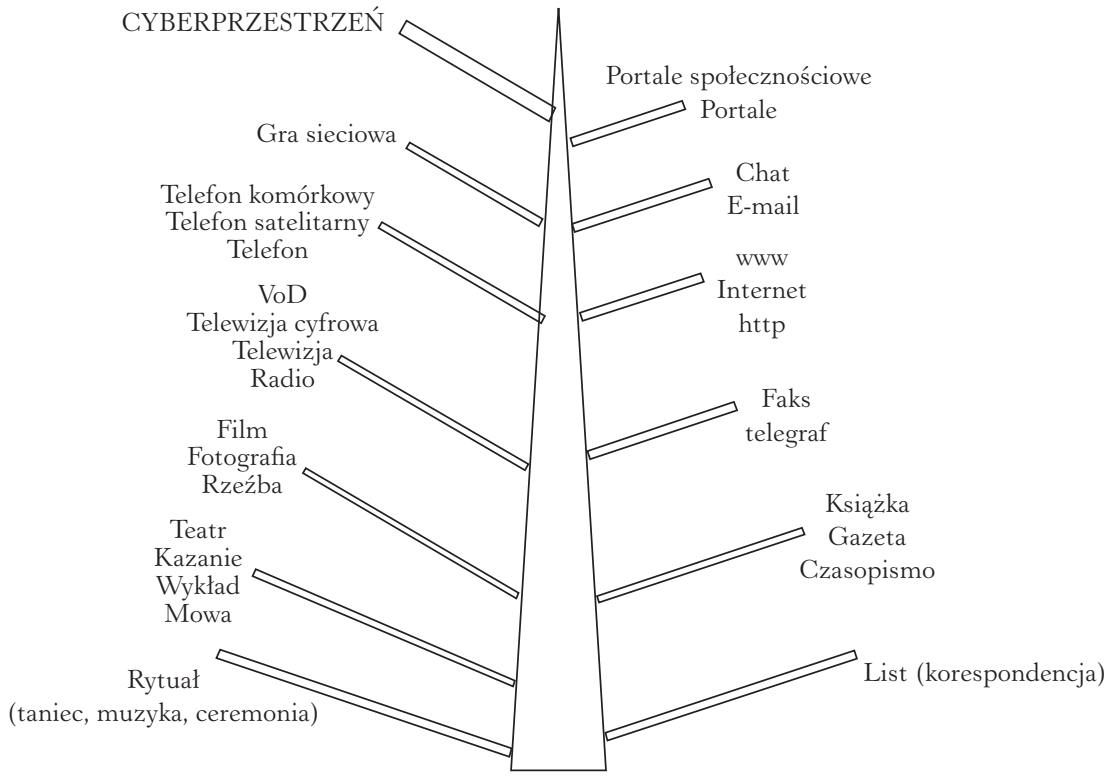

Źródło: na podstawie: B. Siemieniecki (red.), Pedagogika medialna, t. I, Warszawa 2007, s. 154.

Przechodząc do identyfikacji następnego istotnego terminu - cyberprzestrzeni, należy zauważyć, że jest to środowisko, które swój początek miało wraz z powstaniem sieci Internet, najczęściej definiowanej jako ogólnoświatowa sieć komputerowa, tak zwana sieć sieci. Początki Internetu sięgają końca lat 60. XX wieku i związane są bezpośrednio z powstaniem sieci rozległej ARPANET. W wyniku rozwoju technologii i architektury, poprzez łączenie coraz to nowych sieci lokalnych, sieć ta pokryła swoim zasięgiem praktycznie cały obszar kuli ziemskiej i stała się ogólnie dostępna dla większości populacji. Przełomowymi momentami jej rozwoju było opracowanie technologii WWW i pojawienie się portali społecznościowych, które zapoczątkowały rewolucję w dostępie społeczeństwa do informacji. Tym samym system techniczny, jakim jest sieć Internet, przerodził się w system społeczny, jaką jest cyberprzestrzeń.

Pierwsze użycie terminu cyberprzestrzeń przypisuje się Williamowi Gibsonowi, który w 1984 roku użył go w powieści Neuromancer ${ }^{7}$ dla opisania nowego świata. Wprawdzie użyte przez Gibsona określenie cyberprzestrzeni trudno odnieść do świata współczesnej nauki, jednak należy zauważyć, że przed nim nikt inny nie użył takiego terminu w celu

7 W. Gibson, Neuromancer, Londyn 1984. 
wyartykułowania bytu służącego do przetwarzania, przesyłania i przechowywania informacji przez miliardy użytkowników.

W polskim systemie prawnym występuje wiele definicji cyberprzestrzeni. Jedna $z$ nich jest zawarta w nowelizacjach ustaw o stanach nadzwyczajnych ${ }^{8}$, która postrzega cyberprzestrzeń jako przestrzeń przetwarzania i wymiany informacji tworzoną przez systemy teleinformatyczne (w rozumieniu art. 3 pkt 3 ustawy o informatyzacji działalności podmiotów realizujących zadania publiczne ${ }^{9}$ ) wraz z powiązaniami pomiędzy nimi oraz relacjami z użytkownikami. System teleinformatyczny według wspomnianej ustawy o informatyzacji to zespół współpracujących ze sobą urządzeń informatycznych i oprogramowania zapewniający przetwarzanie, przechowywanie, a także wysyłanie i odbieranie danych przez sieci telekomunikacyjne za pomocą właściwego dla danego rodzaju sieci telekomunikacyjnego urządzenia końcowego (w rozumieniu przepisów ustawy Prawo telekomunikacyjne ${ }^{10}$ ). Urządzeniem końcowym w tym ujęciu są urządzenia telekomunikacyjne przeznaczone do podłączenia bezpośrednio lub pośrednio do zakończeń sieci.

Cyberprzestrzeń definiowana jest także w środowisku międzynarodowym. Spośród wielu różnorodnych definicji na uwagę zasługują trzy najważniejsze. Jedną z powszechnie cytowanych definicji jest ta opracowana przez Departament Obrony USA, według której cyberprzestrzeń jest „globalną domeną środowiska informacyjnego składającą się z współzależności (IT) oraz zawartych w nich danych, włączając Internet, sieci telekomunikacyjne a także osadzone w nich procesory i kontrolery" ${ }^{11}$. Należy zauważyć, że definicja ta odnosi się tylko i wyłącznie do sfery technicznej cyberprzestrzeni i nie uwzględnia aspektu społecznego - jej roli i znaczenia dla współczesnych społeczeństw. W Unii Europejskiej cyberprzestrzeń definiowana jest jako „wirtualna przestrzeń, w której krążą elektroniczne dane przetwarzane przez komputery PC z całego świata"12.

8 Ustawa z 30 sierpnia 2011 r. o zmianie ustawy o stanie wojennym oraz o kompetencjach Naczelnego Dowódcy Sił Zbrojnych i zasadach jego podległości konstytucyjnym organom Rzeczypospolitej Polskiej oraz niektórych innych ustaw (Dz.U. z 2011 r. Nr 222, poz. 1323).

9 Ustawa z 17 lutego 2005 r. o informatyzacji działalności podmiotów realizujących zadania publiczne (tekst jedn. Dz.U. z 2019 r., poz. 700).

10 Ustawa z 16 lipca 2004 r. Prawo telekomunikacyjne (t.j. Dz.U. z 2018 r., poz. 1954, ze zm.).

11 Dictionary of Military and Associated Terms, Joint Publication 1-02, DoD, listopad 2010, s. 63.

12 J. Wasilewski, Zarys definicji cyberprzestrzeni, „Przegląd Bezpieczeństwa Wewnętrznego” 2013, nr 9, s. 229. 
Podobnie jak w definicji amerykańskiej sfera użytkownika została także całkowicie pominięta. Według definicji opracowanej na potrzeby NATO w Centrum Doskonalenia Cyberobrony w Tallinie cyberprzestrzeń jest „zależnym od czasu zbiorem połączonych systemów informacyjnych oraz ludzi/użytkowników wchodzących w interakcje z tymi systemami” 13 . W tym ujęciu użytkownik jest ważnym elementem cyberprzestrzeni.

Próbując rozstrzygnąć, czym w takim razie jest cyberprzestrzeń i jakie są jej relacje w stosunku do sieci Internet, należałoby uwzględnić aspekty z obszaru ontologii i teorii systemów. Ale nie o tym tutaj mowa. Najogólniej rzecz ujmując, cyberprzestrzeń stała się środowiskiem umożliwiającym zarówno jednostkom, jak i całym społeczeństwom tworzenie nowych form relacji, kooperacji i funkcjonowania. Należy podkreślić, że główną domeną cyberprzestrzeni, jej istotą, jest informacja. Bez informacji cyberprzestrzeń nie istnieje. A zatem możemy zdefiniować cyberprzestrzeń jako przestrzeń kooperacji międzyludzkich z wykorzystaniem urządzeń elektronicznych do wytwarzania, przechowywania, przekazywania i przetwarzania informacji. Dodatkowo należy podkreślić, że kooperacje te mogę odbywać się w trzech głównych relacjach: człowiek - człowiek, człowiek - cyberprzestrzeń i cyberprzestrzeń - człowiek. W pierwszym przypadku cyberprzestrzeń jest środowiskiem informacyjnym, umożliwiającym wymianę informacji pomiędzy jej użytkownikami. W drugim przypadku cyberprzestrzeń jest środowiskiem, w którym człowiek tworzy swój własny „wirtualny” świat - „wirtualną rzeczywistość”. Trzeci przypadek związany jest z wykorzystaniem sztucznej inteligencji jako elementu cyberprzestrzeni zdolnego do samodzielnego rozwiązywania problemów postawionych przez użytkowników. Powstanie czwartej relacji, cyberprzestrzeń - cyberprzestrzeń, oznaczać będzie koniec świata jaki znamy, ponieważ wiąże się to z usamodzielnieniem i uniezależnieniem sztucznej inteligencji w cyberprzestrzeni. Człowiek w tym przypadku będzie elementem zbędnym. Zidentyfikowanie powyższych realizacji jest niezwykle istotne z punktu widzenia informacyjnego oddziaływania na użytkowników cyberprzestrzeni. Takie narzędzia (sposoby, mechanizmy) jak trolling, boty czy też astroturfing są dzisiaj powszechnie i skutecznie wykorzystywane w kampaniach informacyjnych. Ponadto jeżeli w przedstawionej powyżej definicji cyberprzestrzeni zamienimy słowo „międzyludzkich” na „podmiotów bezpieczeństwa” i wpiszemy jako cel takiej działalności „realizację własnych interesów”, to możemy zauważyć, że cyberprzestrzeń staje się polem rywalizacji. Kooperacje mogą być bowiem i pozytywne,

13 R. Ottis, P. Lorents, Cyberspace: Definition and Implications, Tallin 2010. 
i negatywne. Pierwsze ukierunkowane są na rozwój, te drugie na walkę. Mając na uwadze powyższe, możemy zdefiniować cyberprzestrzeń jako przestrzeń kooperacji podmiotów bezpieczeństwa z wykorzystaniem urządzeń elektronicznych w celu realizacji własnych interesów.

W zaproponowanej definicji użyto określenia „urządzenia elektroniczne" rozumiane jako elementy infrastruktury teleinformatycznej tworzacej środowisko wymiany i przetwarzania informacji. Środowiskiem tym jest sieć Internet i inne sieci teleinformatyczne wykorzystywane do przesyłania, przetwarzania i przechowywania informacji.

Biorąc pod rozwagę znaczenie przestrzeni informacyjnej i cyberprzestrzeni dla funkcjonowania współczesnych społeczeństw, należy skupić się na ich wzajemnych relacjach z następnym ważnym elementem, a mianowicie przestrzenią bezpieczeństwa. Definiowana jest ona jako „niejednorodny zbiór otwarty złożony z podprzestrzeni umożliwiających osiąnięcie zakładanych celów działań, dla których owa przestrzeń została stworzona" ${ }^{14}$. W dobie rozwoju technologii teleinformatycznych i coraz większego zasieggu sieci teleinformatycznych niezwykle trudno jest ustalić, jakie są wzajemne relacje przestrzeni informacyjnej, cyberprzestrzeni i przestrzeni bezpieczeństwa dla podmiotu, jakim jest państwo. Czy przestrzeń informacyjna jest elementem nadrzędnym w stosunku do przestrzeni bezpieczeństwa, czy też relacje te są odwrotne? Zasadna wydaje się odpowiedź, że przestrzeń bezpieczeństwa państwa w obszarze informacyjnym jest elementem składowym cyberprzestrzeni, która z kolei wchodzi w skład przestrzeni informacyjnej, co przedstawiono na rysunku 3.

Rysunek 3. Wzajemne relacje przestrzeni bezpieczeństwa, cyberprzestrzeni i przestrzeni informacyjnej

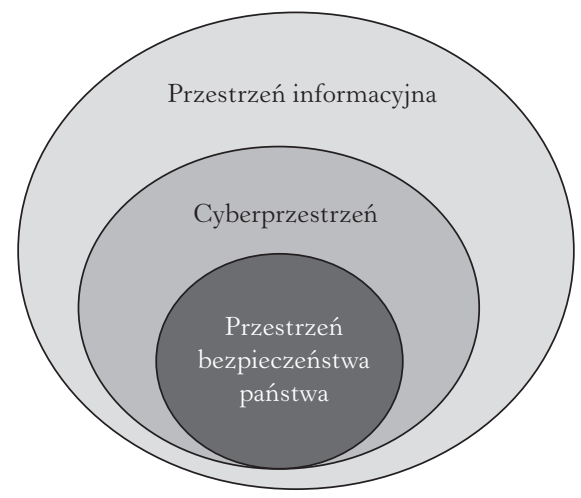

Źródło: opracowanie własne.

14 R. Kwećka, Strategia bezpieczeństwa..., s. 20. 


\section{Bezpieczeństwo informacyjne - obszary aktywności}

Nie można mówić o propagandzie w oderwaniu od bezpieczeństwa informacyjnego, którego integralnymi elementami są walka informacyjna i jej składowa - dezinformacja. Bezpieczeństwo informacyjne, w odróżnieniu od bezpieczeństwa informacji, jest pojęciem złożonym i dużo trudniejszym do uchwycenia. To drugie bowiem najczęściej ogranicza się do spełnienia trzech atrybutów informacji, takich jak poufność, dostępność i integralność. Osiągane jest w trzech obszarach: organizacyjnym, technicznym i fizycznym poprzez implementację między innymi systemu zarządzania bezpieczeństwem informacji bazującym na przyjętych normach, na przykład ISO 27001. Natomiast bezpieczeństwo informacyjne wykracza w istotny sposób poza ramy obowiązujących norm. Informacja funkcjonująca w przestrzeni informacyjnej stała się narzędziem i środkiem realizacji przyjętych celów działania. W bezpieczeństwie informacyjnym niezwykle istotne jest, oprócz zapewnienia bezpieczeństwa informacji, stosowanie elementów walki informacyjnej z elementami dezinformacji i propagandy. Ich umiejętne wykorzystanie pozwala nie tylko na działanie z pozycji dodatniej w stosunku do potencjalnych adwersarzy, ale także pozwala kreować rzeczywistość stawiającą dowolny podmiot bezpieczeństwa zarówno w korzystnym, jak i niekorzystnym świetle. Co więcej, każdy podmiot bezpieczeństwa musi być równocześnie świadomy, że także on może być (a nawet jest) celem oddziaływania informacyjnego, celem propagandy ukierunkowanej na dyskredytację, zmniejszenie wpływów, poniesienie wymiernych strat. Zdolność skutecznego przeciwstawienia się wrogiej kampanii informacyjnej i identyfikacji tego, kto za nią stoi, staje się newralgicznym elementem funkcjonowania każdego państwa i najważniejszym czynnikiem skutecznego działania. Spłaszczanie problemu tylko i wyłącznie do ochrony zasobów informacyjnych nie gwarantuje w XXI wieku działania z pozycji dodatniej.

Bezpieczeństwo informacyjne to transsektorowy obszar bezpieczeństwa, który odnosi się do środowiska informacyjnego (przestrzeni informacyjnej). Jest to proces, którego celem jest zapewnienie prawidłowego i zarazem bezpiecznego funkcjonowania podmiotu bezpieczeństwa $\mathrm{w}$ przestrzeni informacyjnej poprzez panowanie we własnej infosferze w celu zabezpieczenia własnych interesów, w przypadku państwa - interesów narodowych. Realizacja powyższego wymaga: zapewnienia odpowiedniej ochrony posiadanych zasobów informacyjnych, przeciwstawienia się wrogim działaniom dezinformacyjnym i propagandzie oraz prowadzenia aktywnych informacyjnych działań ofensywnych wobec adwersarzy. 
Zadania te powinny znaleźć odzwierciedlenie w strategii każdego państwa, a ich implementacja powinna umożliwić stworzenie systemu bezpieczeństwa informacyjnego ${ }^{15}$. Bezpieczeństwo informacyjne występuje w środowisku wewnętrznym, zewnętrznym, militarnym, niemilitarnym, osobowym, społecznym, technologicznym i wielu innych. Dla zapewnienia całościowego bezpieczeństwa informacyjnego ważne jest zidentyfikowanie celów realnych i głównych niewiadomych, które powinny być rozpatrywane z uwzględnieniem obszarów: zagrożeń, wyzwań, szans i ryzyka.

Bezpieczeństwo informacyjne, w ocenie autora, jest najbardziej wrażliwym obszarem bezpieczeństwa zarówno w państwie, jak również na arenie międzynarodowej. Ma wpływ na skuteczność i efektywność funkcjonowania całego systemu bezpieczeństwa tak narodowego, jak i międzynarodowego. Dodatkowo należy zauważyć, że działania podejmowane w obszarze bezpieczeństwa informacyjnego muszą być podejmowane z uwzględnieniem praw człowieka i obywatela, a w szczególności z poszanowaniem prawa do prywatności i wolności słowa, co nie jest takie proste i oczywiste.

Nieodzownym elementem bezpieczeństwa informacyjnego jest walka informacyjna. Pierwotnie walka informacyjna kojarzona była z prowadzeniem wojny. Współcześnie jest ona elementem polityki podmiotów bezpieczeństwa takich jak państwa czy też korporacje, a ich głównym celem jest działanie z pozycji dodatniej w stosunku do konkurenta (przeciwnika). Zdobywanie informacji, ochrona własnych zasobów informacyjnych oraz prowadzenie kampanii informacyjnych (z elementami propagandy i dezinformacji, ang. denial and deception) będą odgrywały coraz większą rolę w otaczającym nas świecie.

Termin walka informacyjna po raz pierwszy został użyty dopiero w latach 90. XX wieku. Amerykański ekspert Winn Schwartau w książce Information Warfare ${ }^{16}$ zdefiniował walkę informacyjną jako „działania ukierunkowane na ochronę, uszkodzenie, wykorzystanie, zniszczenie informacji, jak i zasobów informacji, ale i również zaprzeczenie informacjom po to, aby osiągnąć swój cel, korzyści lub nawet zwycięstwo nad przeciwnikiem”17. Niemniej jednak najstarsze zapisy, które odnoszą się do elementów walki informacyjnej, pojawiły się już w VI wieku p.n.e.

\footnotetext{
15 Z. Nowakowski, H. Szafran, R. Szafran, Bezpieczeństwo w XXI wieku. Strategia bezpieczeństwa narodowego Polski $i$ wybranych państw, Rzeszów 2009, s. 67.

16 W. Schwartau, Information Warfare: Chaos on the Electronic Superhighway, Nowy Jork 1994.

17 P. Bączek, Zagrożenia informacyjne a bezpieczeństwo państwa polskiego, Toruń 2006, s. 132.
} 
w książce Sztuka wojny Sun Tzu. Można w niej znaleźć zapis: „jeśli wiem, że moje oddziały mogą uderzyć na wroga, lecz nie wiem, czy wróg jest przygotowany do odparcia, to szansa przegranej i wygranej jest jak jeden do jednego. Tak samo, jeśli wiem, że wróg nie jest przygotowany na atak, lecz nie wiem czy moje oddziały są gotowe do uderzenia, szansa zwycięstwa i poraźki jest jak jeden do jednego. Jeśli wiem, że moje oddziały mogą uderzyć i wróg nie jest przygotowany na atak, lecz nie rozpoznałem dobrze ułożenia terenu bitwy, szansa zwycięstwa i porażki jest jak jeden do jednego. Dlatego też twierdzę: Poznaj warunki terenu i pogody, wtedy Twoje zwycięstwo będzie całkowite"18.

$\mathrm{Z}$ powyższego można wnioskować, że działania te ukierunkowane były na:

- poznanie wroga, pogody i terenu, czyli dzisiejsze rozpoznanie;

- poznanie siebie, czyli zapewnienie niezakłóconego funkcjonowania własnego systemu informacyjnego;

- wprowadzanie komunikatów zakłócających, czyli dzisiejsza dezinformacja.

Walkę informacyjną określa się także jako wojnę informacyjną (i odwrotnie). Jest to określenie często wykorzystywane przez polityków, którzy w ten sposób chcą wyrazić swoje nastawienie do zaistniałej sytuacji. Zjawisko to jest już tak powszechne, że obecnie trudno określić, co jest wojną informacyjną, a co wojną informacyjną jeszcze nie jest.

Elementem składowym walki informacyjnej jest dezinformacja, definiowana współcześnie jako „wprowadzenie kogoś w błąd przez podanie mylących lub fałszywych informacji” ${ }^{19}$. Termin ten pojawił się po raz pierwszy w literaturze anglojęzycznej w 1926 roku w londyńskim miesięczniku „The Whitehall Gazette \& St. James’s Review”20. Określenia tego użyto w celu opisania działań sowieckich służb specjalnych. Rok później w piśmie „Siegodnia” wspomniano, iż należy ona do głównych działań GPU (Państwowego Zarządu Politycznego przy Ludowym Komisariacie Spraw Wewnętrznych Rosyjskiej Federacyjnej Socjalistycznej Republiki Radzieckiej) ${ }^{21}$.

Kolejną interpretacją zjawiska dezinformacji jest definicja podana przez Vladimira Volkoffa, który postrzega ją „w wąskim lub szerszym

18 Sun Tzu, Sztuka wojny, przekł. K.A.M., Warszawa 1994, s. 116.

19 Hasło: Dezinformacja, „Słownik języka polskiego”, https://sjp.pwn.pl/sjp/dezinformacja;2554971.html (dostęp: 22.12.2018).

20 The Embassies and Foreign Affairs, „The Whitehall Gazette \& St. James's Review” 1926, maj, s. 8.

21 J.J. Dziak, Chekisty: A History of the KGB, Lexington 1987, s. 42. 
znaczeniu. W wąskim tego słowa znaczeniu mieści się ona w połowie drogi między wprowadzeniem w błąd a wpływaniem. Podczas gdy wprowadzanie w błąd [...] jest czynnością jednorazową, związaną z konkretnym zadaniem, dopuszcza pewną amatorszczyznę, wykorzystuje najprzeróżniejsze środki i zmierza do wmówienia pewnych określonych rzeczy określonym osobom, dezinformacja jest prowadzona w sposób systematyczny, fachowy, zawsze za pośrednictwem mass mediów i jest adresowana do opinii publicznej, a nie sztabów krajów - obiektów działań. I analogicznie: podczas gdy wpływanie przejawia się w działaniach pozornie niezorganizowanych, oportunistycznych, głównie ilościowych, dezinformacja stawia sobie za cel realizację konsekwentnego programu zmierzającego do zastąpienia w świadomości, a przede wszystkim podświadomości mas będących przedmiotem tych działań, poglądów uznanych za niekorzystne dla dezinformatora takimi, które uważa on za korzystne dla siebie"22. Volkoff wymienił także kilka metod dezinformacji, takich jak: odwrócenie faktów, negacja faktów, mieszanie prawdy i kłamstwa, rozmycie, kamuflaż, interpretacja, generalizacja, ilustracja, nierówna reprezentacja, równa reprezentacja ${ }^{23}$. Techniki te, wykorzystywane we wszelkiego rodzaju manipulacjach informacyjnych oraz kampaniach dezinformacyjnych, nie wyczerpują całości metod i narzędzi wykorzystywanych w walce informacyjnej.

Początków dezinformacji możemy doszukiwać się patrząc daleko wstecz, do najstarszych rozwiniętych cywilizacji czy też początków zorganizowanych konfliktów zbrojnych. Przykładem może być myśl Sun Tzu, który w cytowanej już wcześniej książce Sztuka wojny stwierdził, że „wojna jest to wprowadzanie w błąd. Jeśli zatem jesteś zdolny, udawaj mało zdolnego. Gdy porywasz swoje wojska do działania, udawaj bierność. Jeżeli twój cel jest bliski, zachowuj się tak, jakby był odległy. A gdy jest odległy, udawaj, że jest bliski”24. W każdej bowiem wojnie czy też konflikcie zbrojnym niezbędnym newralgicznym elementem jest umiejętność i zdolność wprowadzania przeciwnika w błąd, poprzez podawanie nieprawdziwych informacji i tworzenie fałszywej rzeczywistości. Dezinformacja jest zjawiskiem ponadczasowym, bardzo mocno zapisanym w naszej przeszłości, teraźniejszości i zapewne w przyszłości. Można wręcz pokusić się o tezę, że jest naturalnym elementem rozwoju ludzkości.

\footnotetext{
22 V. Volkoff, Psychosocjotechnika, dezinformacja - oręż wojny, przekł. A. Arciuch, Warszawa 1999, s. 8.

23 Tamże, s. 157-172.

24 Sun Tzu, Sztuka wojny, przekł. K.A.M.,, Warszawa 1994, s. 61.
} 
Dezinformacja może mieć zarówno wymiar strategiczny, jak i taktyczny. Dezinformacja taktyczna trwa zazwyczaj stosunkowo krótko, kilka miesięcy, a jej głównym celem jest wprowadzenie w błąd w jednej lub kilku powiązanych ze sobą kwestiach. Przykładami tego rodzaju dezinformacji mogą być:

- podsunięcie nieprawdziwych danych technicznych nowej broni;

- zmodyfikowanie danych statystycznych celem wywołania wrażenia, iż stan ekonomii danego państwa jest lepszy lub gorszy od rzeczywistego;

- opublikowanie sfabrykowanych materiałów w celu skompromitowania polityka, partii czy też nawet rządu.

Z kolei dezinformacja strategiczna polega na systematycznym przekazywaniu sfabrykowanej informacji oraz fałszywych sygnałów politycznych. Jej głównym celem jest wytworzenie wypaczonego obrazu rzeczywistości powodującego błędną analizę sytuacji. To działanie ukierunkowane na wprowadzenie w błąd przeciwnika co do podstawowych kwestii polityki państwa ${ }^{25}$. W przeciwieństwie do dezinformacji taktycznej trwa ona nawet kilkadziesiąt lat i należy, w głównej mierze, do sfery walki służb specjalnych. Więcej informacji na ten temat można znaleźć w doskonałej książce Roya Godsona i Jamesa J. Wirtza Strategic Denial and Deception ${ }^{26}$.

\section{Istota i elementy propagandy}

Przechodząc do tematu propagandy, można zauważyć, że także ona jest bezpośrednio związana z historią ludzkości. Z pierwszymi przykładami takich działań mieliśmy do czynienia już w kulturze mezoamerykańskiej i egipskiej, gdzie zapisy hieroglificzne składające się głównie z symboli i obrazów przedstawiały historię w sposób korzystny dla władzy. Było to możliwe dzięki temu, że jedynie władcy i ich kapłani posiadali umiejętność tworzenia hieroglifów, przez co perswazja była jednokierunkowa, skierowana od władcy do mas. Pierwsze zapisy, w których użyto określenia propaganda, odnotowano w 1622 roku, wraz z powołaniem przez Papieża Grzegorza XV Kongregacji Propagandy Wiary (Congregatio de Propaganda Fide). Do powszechnego obiegu pojęcie to weszło

25 S. Lewczenko, Private Channel, [w:] Influence: A KGB Disinformation Tool, „Counterpoint: A Monthly Report on Soviet Active Measures” 1988, t. 3, nr 11, s. 1.

26 R. Godston, J.J. Wirtz, Strategic Denial and Deception. The Twenty-First Century Challenge, Waszyngton 2012. 
podczas I wojny światowej jako nowa technika perswazji, oddziaływania na społeczeństwo 27 . Propagandę postrzegano wtedy jako rozprzestrzenianie stronniczych idei i poglądów, w praktyce często używając przy tym kłamstwa, manipulacji i podstępu. Największy rozwój propagandy związany był z systemami totalitarnymi: faszyzmem i komunizmem. Od tego czasu obejmuje ona również sugestię i wywieranie wpływu przy użyciu manipulacji symbolami i mechanizmami psychologicznymi. Propaganda to także zręczne posługiwanie się obrazami i sloganami, z odwoływaniem się przy tym do uprzedzeń czy emocji. Jest to pewnego rodzaju komunikat stworzony na potrzeby zdefiniowanego (określonego) punktu widzenia - celem jest skłonienie odbiorcy tego komunikatu do dobrowolnego przyjęcia zawartego w nim punktu widzenia i uznania go za swój ${ }^{28}$. Współcześnie propaganda definiowana jest jako „proces składający się z planowanego użycia każdej formy publicznych lub masowo wytwarzanych komunikatów zaprojektowanych tak, aby wpływały na umysły i emocje wybranej grupy odbiorców, w z góry określonym celu (społecznym, militarnym, ekonomicznym, politycznym)"29. Kluczowymi elementami propagandy są przyjęty plan działania i cele, jakie ten plan realizuje. Bez planu i celowości działania nie można mówić o propagandzie, lecz jedynie o kłamstwie lub manipulacji. Nie każde kłamstwo i manipulacja stosowane w życiu publicznym są propagandą, ale każda kampania propagandowa jest oparta na kłamstwach i manipulacji.

Mówiąc o schemacie, według którego realizowana jest kampania propagandowa, należy odnieść się do zapisów przedstawionych przez Paula M.A. Linebargera w książce Psychological Warfare. Wymienia on pięć najważniejszych etapów propagandy, określanych łącznie jako STASM od pierwszych liter ich angielskich nazw, a mianowicie ${ }^{30}$ :

- $\mathrm{S}$ - source (źródła - kanały informacyjne propagandy);

- T - time (czas rozpoczęcia i prowadzenia kampanii propagandowej);

- A - audience (publiczność - odbiorcy propagandy);

- $\mathrm{S}$ - subject (temat - sprawa, której dotyka kampania propagandowa);

- $\mathrm{M}$ - mission (misja - cel kampanii propagandowej powiązany z celem politycznym).

27 E. Aronson, A. Pratkanis, Wiek propagandy, przekł. J. Radzicki, M. Szuster, Warszawa 2004, s. 17.

28 A. Chorobiński, Walka informacyjna jako fundamentalny składnik działalności terrorystycznej w przyszłości, s. 4, http://konkursy.byd.pl/userfiles/files/chorobinski.pdf (dostęp: 22.12.2018).

29 P.M.A. Linebarger, Psychological Warfare, Waszyngton 1954 (1972), s. 61.

30 Tamże, s. 67. 
Pierwszy element dotyczy źródeł informacji (kanałów informacyjnych), przez które będzie prowadzona kampania propagandowa. Współcześnie są to: prasa, telewizja, ulotki, Internet, wiece, bezpośrednie spotkania, fałszywe autorytety, agenci wpływu itp. „Czas” to nic innego jak określenie, kiedy i jak długo kampania będzie prowadzona. Określenie czasu jest bardzo istotne, ponieważ łatwiej jest wpływać na społeczeństwo będące w kryzysie, stojące przed wyzwaniami lub wyborami. Dobór czasu jest uwarunkowany w głównej mierze percepcją grupy docelowej i budowaniem w niej odpowiednich przekonań i poglądów (psychologia tłumów). Publiczność - grupa docelowa kampanii - charakteryzuje się swoimi systemami wartości, przekonaniami, nawykami, środowiskiem informacyjnym, z którego pozyskuje wiedzę na temat otaczającego świata. Inny przekaz będzie kierowany do ludzi wykształconych, świadomie korzystających ze sprawdzonych źródeł informacji, inny z kolei do grupy osób budujących swoje spojrzenie na świat na podstawie na przykład mediów społecznościowych czy też konkretnych (ulubionych) kanałów informacyjnych. Temat propagandy powinien być bezpośrednio związany z oczekiwaniami wybranej grupy docelowej, niejako rozwiązujący stojące przed nią problemy. Ostatni aspekt to cel (misja), dla którego prowadzone są działania propagandowe. Jest to podstawowy element, który musi zostać określony zaraz na początku planowania kampanii propagandowej. Oczywiście nie jest to cel sam w sobie - jest ściśle powiązany z celem politycznym, militarnym, ekonomicznym, marketingowym, społecznym.

Patrząc przez pryzmat współczesnego społeczeństwa i środowiska informacyjnego, w którym ono funkcjonuje, można zauważyć, że proces propagandy uwarunkowany jest wieloma czynnikami, takimi jak: działalność propagandystów, media społecznego przekazu, sieci i media społecznościowe, organizacje rządowe i pozarządowe, grupy społeczne, systemy wartości, kultura i tradycje, systemy ekonomiczne i polityczne oraz wiele, wiele innych. Komunikaty wysyłane w propagandzie funkcjonują w szeroko pojmowanej obręczy kulturowej (ang. cultural rim), która z kolei uwarunkowana jest kontekstem społeczno-historycznym (ang. social-historical context). Z tego powodu nie można rozpatrywać propagandy w oderwaniu od historycznych ram kulturowych. Każde społeczeństwo funkcjonuje bazując na innych systemach wartości, uwarunkowanych kulturą, doświadczeniami, przekonaniami i historią. Propaganda uwzględniająca powyższe aspekty ma wpływ na kształt kultury, ale także kultura ma wpływ na kształt propagandy. $\mathrm{Na}$ rysunku 4 przedstawiono model współczesnej propagandy. 
Rysunek 4. Model współczesnej propagandy

SOCIAL-HISTORICAL CONTEXT

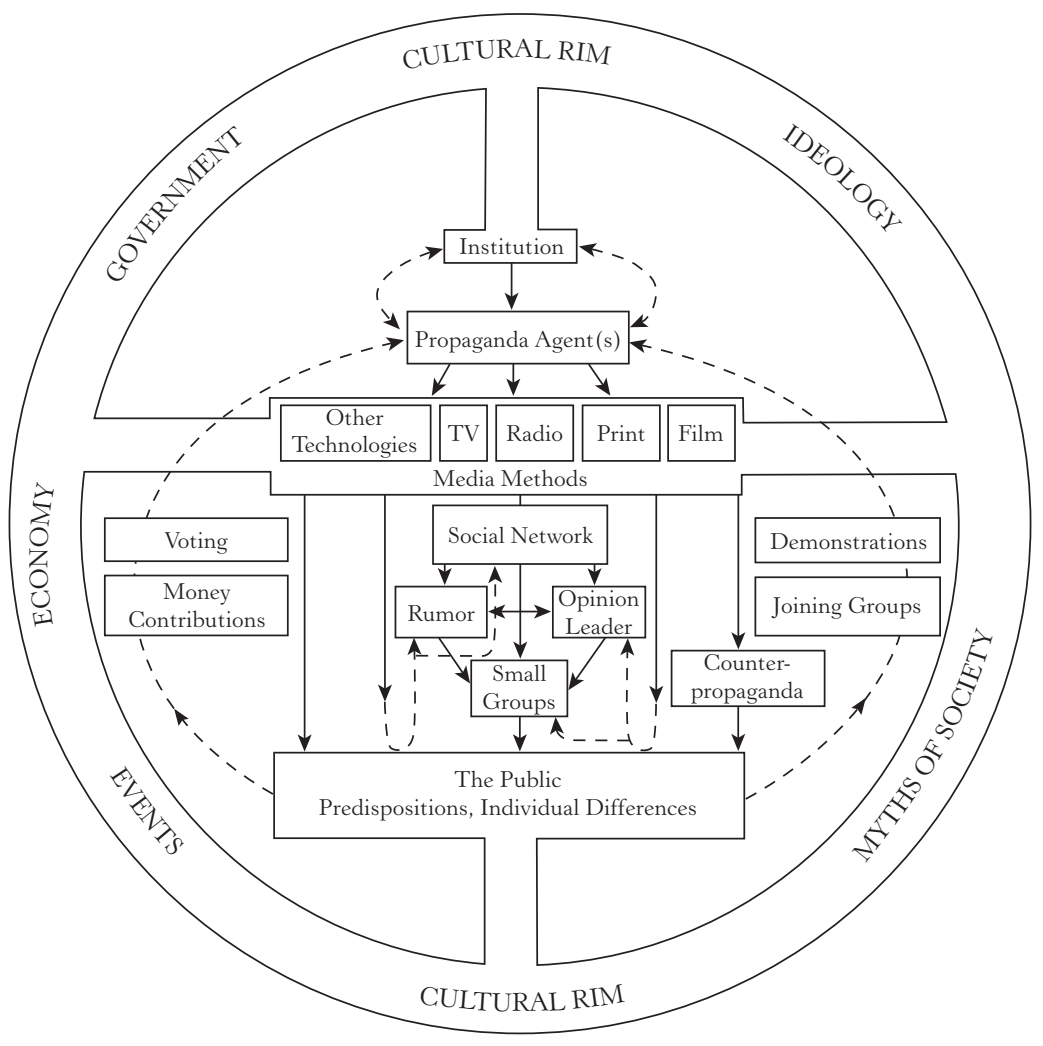

Źródło: G.S. Jowert, V. O’Donnell, Propaganda and Persuasion, Waszyngton 2006, s. 361.

Na rysunku 4 uwidocznione zostały ścisłe powiązanie procesu propagandy ze społeczeństwem, w którym jest ona realizowana, a zwłaszcza z jego społeczno-historycznymi i kulturowymi uwarunkowaniami. Dlatego propagandyści, chcąc być skuteczni, muszą uwzględniać wszystkie aspekty dziedzictwa narodowego społeczeństwa, mające odzwierciedlenie w stylu, sposobie i narracji przekazu. Tym samym także identyfikowanie kampanii propagandowych wymaga uwzględnienia kontekstu społeczno-historycznego i kulturowego społeczeństwa, w którym była ona prowadzona. Patrząc przez pryzmat ostatnich wydarzeń w naszej części Europy, zauważamy, że w rosyjskiej propagandzie inna narracja wykorzystywana jest w kampanii wymierzonej w realizację celów politycznych na Ukrainie, a inna w Polsce. Adresatem przekazu jest nie tylko społeczeństwo danego kraju, ale także 
społeczeństwo rosyjskie, rosyjskojęzyczne i międzynarodowe. W przypadku Ukrainy głównym tematem narracji jest nacjonalizm ukraiński i porównywanie Ukraińców do faszystów i banderowców, wsparte dodatkowo przekazem o upadku korupcyjnego państwa, w którym oligarchowie i władza kradną, a reszta społeczeństwa klepie biedę. W przypadku Polski narracja ukierunkowana jest na rusofobię, antysemityzm, niewdzięczność za wyzwolenie, nacjonalizm Polaków oraz zgubny wpływ Unii Europejskiej na tożsamość i niezależność narodową. Ponadto w przypadku Polski, w myśl zasady dziel i rządź, w propagandzie wykorzystywany jest temat katastrofy smoleńskiej, którego najistotniejszym elementem jest wrak polskiego samolotu, polaryzujący polskie społeczeństwo. Faktem jest to, że dopóki wrak samolotu będzie dzielił polskie społeczeństwo, dopóty Rosja nie przekaże go Polakom. W tym przypadku przekazy propagandowe wspierane są dodatkowo agenturą wpływu mającą swoje korzenie we wspólnej rosyjsko-polskiej historii. W czasach zaborów, okupacji i PRL Rosjanie budowali w polskim społeczeństwie siatkę agentów i donosicieli, zarówno wśród opozycji jak i w obozie rządzącym. Dzisiaj ich teczki znajdują się w Moskwie i są podstawą budowania silniej agentury wpływu. Oczywiście nie ma na to jednoznacznych dowodów, ale które z państw zrezygnowałoby $z$ agentury wpływu, mając $w$ swoich archiwach narzędzia oddziaływania i szantażu? (Tak na marginesie, w przypadku Polski osobnym zagadnieniem wymagającym zbadania jest niemiecka agentura wpływu, budowana na bazie agentury III Rzeszy i Stasi).

Kończąc powyższe rozważania, należy jeszcze raz podkreślić, że propaganda będzie wtedy skuteczna, jeżeli jest zaplanowana długofalowo, a u podstaw jej tworzenia zostaną uwzględnione uwarunkowania społeczno-historyczne i kulturowe danego społeczeństwa. Najlepszym przykładem takiego oddziaływania jest zakorzenienie w społeczeństwach zachodnich określenia „polski obóz śmierci”. I chociaż jest to oczywiste kłamstwo historyczne, to jest w dalszym ciągu wykorzystywane przeciwko Polsce i Polakom. Szczytem zarówno historycznej ignorancji, jak i skuteczności antypolskiej propagandy była wypowiedź prezydenta Baracka Obamy z 2012 roku, kiedy użył określenia polish death camps ${ }^{31}$.

31 Obama Angers Poles with „Death Camp” Remark, BBC News, 30.05.2012, https://www. bbc.com/news/world-europe-18264036 (dostęp: 22.12.2018); Obama's Words at Medal Ceremony Cause Trouble with Poland, CNN Wire Staff, 30.05.2012, https://edition. cnn.com/2012/05/30/politics/obama-death-camps/index.html (dostęp: 22.12.2013); M. Landler, Polish Premier Denounces Obama for Referring to a „Polish Death Camp”, „The New York Times”, 30.05.2012, https://www.nytimes.com/2012/05/31/world/europe/ poland-bristles-as-obama-says-polish-death-camps.html (dostęp: 22.12.2018). 
Kolejnym obszarem wymagającym zidentyfikowania w propagandzie jest jej źródło i stopień prawdziwości czy też zakłamania, co pozwala wyróżnić trzy podstawowe rodzaje propagandy ${ }^{32}$ : białą (ang. overt or white propaganda), szarą (ang. gray propaganda) i czarną (ang. covert or black propaganda).

Pierwsza z nich, propaganda biała, to działania, w których źródło i pochodzenie informacji są znane odbiorcy. Jest to nic innego jak przekazanie oficjalnego stanowiska rządu, agencji rządowej czy też organizacji w sposób jawny, z tym że przekazywane w nich informacje są podawane w sposób wybiórczy, z uwypukleniem tych sprzyjających stronie przekazującej i jednocześnie z pomijaniem faktów niewygodnych dla niej.

Szara propaganda cechuje się tym, że źródło informacji nie jest do końca znane, jedynie można się domyślać jego pochodzenia, przy tym przekazywana w niej informacja może być bądź korzystna, bądź niekorzystna dla określonej grupy odbiorców. Informacje podawane są w taki sposób, aby nosiły one zmamiona przecieku informacyjnego, nieoficjalnego stanowiska rządu czy też organizacji.

Ostatni rodzaj - czarna propaganda - jest z założenia budowana na kłamstwie i fałszu. Zarówno źródło informacji, jak i sama informacja są fałszywe. Celem tego typu działań jest uzyskanie w grupie odbiorców odpowiedniego efektu psychologicznego polegającego na całkowitej zmianie postrzegania bieżącej sytuacji politycznej, społecznej, ekonomicznej, militarnej itp. W dobie cyberprzestrzeni czarna propaganda jest narzędziem powszechnie wykorzystywanym, chociażby w czasie wyborów, referendów czy w innych ważnych dla danego społeczeństwa sytuacjach.

Podobnie jak w przypadku dezinformacji, także w przypadku propagandy można wyróżnić jej dwie zasadnicze kategorie, a mianowicie propagandę taktyczną i propagandę strategiczną ${ }^{33}$. Są one nierozerwalnie związane z czasem ich prowadzenia i przyjętym celem oddziaływania. Najczęściej formy te wykorzystywane są w trakcie operacji militarnych, ale ostatnio także w elementach tak zwanej wojny hybrydowej. Propaganda strategiczna ukierunkowana jest na realizację celów strategicznych, rozłożonych w długim przedziale czasu, często sięgającym nawet lat, a jej głównym celem jest zbudowanie nowej świadomości (nowego postrzegania bieżącej sytuacji) wśród grupy docelowej. Propaganda taktyczna skierowana jest bezpośrednio do wybranej grupy odbiorców, na przykład żołnierzy biorących udział w danej operacji, w celu wywarcia na nich

32 G.S. Jowert, V. O’Donnell, Propaganda and Persuasion, Waszyngton 2006, s. 17.

33 P.M.A. Linebarger, Psychological..., s. 69. 
odpowiedniego wrażenia, przekonania do własnej racji, zdemotywowania do działania i poświęceń. Jej czas oddziaływania związany jest bezpośrednio z czasem realizacji danej operacji militarnej.

W literaturze przedmiotu można zidentyfikować także inne jej rodzaje i formy. I tak, w zależności od rodzaju aktywności stron prowadzących kampanie propagandowe, wyróżniamy ${ }^{34}$ propagandę defensywną (ang. defensive propaganda) i propagandę ofensywną (ang. offensive propaganda). Pierwsza z nich wykorzystywana jest do wzmocnienia pozytywnego nastawienia społeczeństwa i akceptacji w stosunku do planów i przedsięwzięć podejmowanych, realizowanych przez państwo (rząd, organizację). Drugi rodzaj propagandy wykorzystywany jest w celu przerwania i zmiany negatywnego nastawienia społeczeństwa, niezgodnego z celami propagandystów.

$\mathrm{Z}$ punktu widzenia celu oddziaływania propagandy na społeczeństwo wyróżniane są następujące jej rodzaje ${ }^{35}$ :

- propaganda konwersyjna (ang. conversionary propaganda) - jej głównym celem jest zmiana świadomości, poglądów i lojalności jednostki w stosunku do danej grupy społecznej i ich przekierowania na inną, pożądaną grupę społeczną;

- propaganda dzieląca (ang. divisive propaganda) - ukierunkowana jest na rozbicie wybranej społeczności (grupy), tak aby powstały w niej podziały (mniejsze grupy), a tym samym zmniejszyła się jej siła oddziaływania;

- propaganda scalająca (ang. consolidation propaganda) - charakteryzują ją odmienne cele, jej głównym zadaniem jest likwidacja podziałów i zjednoczenie społeczeństwa wokół wspólnej sprawy, wspólnego celu;

- przeciwpropaganda (ang. counter propaganda) - jest w swej istocie nastawiona na osłabienie lub téz całkowite uniemożliwienie realizacji celów propagandy stosowanej przez przeciwnika zarówno militarnego, politycznego czy gospodarczego.

Następnym istotnym elementem wymagającym zidentyfikowania są techniki, przy pomocy których propaganda jest realizowana. Do najważniejszych z nich można zaliczyćc ${ }^{36}$ : zapewnienie (ang. assertion), owczy pęd (ang. bandwagon), naciagganie faktów (ang. card stacking), błyskotki (ang. glittering generalities), mniejsze zło (ang. lesser of two evils), docze-

34 Tamże, s. 70.

35 Tamże.

36 Na podstawie materiałów uzyskanych przez autora w ramach przedmiotu Foreign Propaganda, Perceptions, and Policy, realizowanego w semestrze jesiennym 2017 r. w The Institute of World Politics, Washington D.C. 
pianie ogólników (ang. name calling), wskazywanie wroga (ang. pinpointing the enemy), ludowość (ang. plain folks), uproszczenie (ang. simplification), referencja (ang. testimonials), przenoszenie (ang. transfer).

Zapewnienie (ang. assertion) jest współczesną techniką propagandy powszechnie stosowaną w reklamie. Przekazywane informacje mają entuzjastyczny, radosny, energiczny charakter, a treści w nich zawarte, niekoniecznie prawdziwe, odwołują się do przekonań i nastawienia odbiorców. Coś jest z natury dobre, bo jest, bez żadnego udawadniania i odwoływania się do faktów, bez zadawania zbędnych pytań. Za każdym razem, gdy reklamodawca stwierdzi, że jego produkt jest najlepszy, bez dostarczania naukowych dowodów, korzysta z techniki zapewnienia. Odbiorca informacji zgadza się z otrzymywanym przekazem bezrefleksyjnie, nie dążąc do zidentyfikowania, jak jest naprawdę. Zapewnienie, choć dosyć łatwe do wykrycia, jest coraz częściej wykorzystywane w polityce do sterowania emocjami społecznymi, a narracja takiego przekazu jest, z natury rzeczy, budowana na fałszu i kłamstwie ${ }^{37}$.

Owczy pęd (ang. bandwagon) jest jedną z najpopularniejszych technik propagandy stosowaną zarówno w czasie wojny, jak i pokoju i odgrywa bardzo ważną rolę we współczesnej inżynierii społecznej. Polega na apelu do odbiorcy o podążanie za tłumem, za większością, ponieważ inni też to robią i będzie to tylko i wyłącznie z korzyścią dla niego. W tym przypadku propagandysta zasadniczo stara się przekonać odbiorcę, że tylko jedna ze stron, ta właściwa, jest zwycięską, ponieważ dołączyło do niej więcej osób i z tego też względu tylko oni mają rację. Odbiorcy mają wierzyć, że skoro tak wielu ludzi dołączyło, to zwycięstwo jest nieuniknione, a porażka niemożliwa. Przeciętna osoba zawsze chce być po zwycięskiej stronie, więc jest zmuszona presją tłumu do przyłączenia się. Przeciwdziałanie tej technice propagandy polega w głównej mierze na szczegółowym rozważeniu plusów i minusów przyłączania się do sugerowanej idei bez uwzględniania liczby osób, które już się do niej dołączyły. Odbiorca powinien poszukiwać więcej informacji, uzyskanych z wielu niezależnych źródeł38.

Technika naciągania faktów (ang. card stacking) polega na przedstawianiu informacji jedynie pozytywnych, sprzyjających propagandystom, z pominięciem informacji dla nich negatywnych. Ze względu na swoją wysoką skuteczność jest ona powszechnie stosowana w życiu społecznym

37 H.T. Conserva, Propaganda Techniques, Bloomington 2003, s. 25-27.

38 W. Garber Propaganda Analysis - to What Ends, „The American Journal of Sociology” 1942, t. 48 , nr 2, s. 240. 
i politycznym. Chociaż większość informacji przedstawionych przez propagandystę jest prawdziwa, to jednak pomija się w przekazie to, co jest istotne, ale równocześnie niekorzystne dla propagandysty. Najlepszym sposobem radzenia sobie $\mathrm{z}$ naciąganiem faktów jest zdobycie większej liczby informacji ${ }^{39}$.

Błyskotki lub też błyszczące ogólniki (ang. glittering generalities) to technika wykorzystywana najczęściej w polityce i politycznej propagandzie polegająca na używaniu słów mających pozytywne znaczenie dla poszczególnych odbiorców przekazu propagandowego i powiązanych bezpośrednio z wysoko cenionymi wartościami. Użyte słownictwo jest przyjmowane (akceptowane) bezrefleksyjnie, automatycznie, bez zastanowienia, tylko i wyłącznie dlatego, że dotyczy ważnego dla odbiorcy pojęcia. Słowa często używane w technice błyskotek to: honor, ojczyzna, bóg, chwała, miłość do kraju, demokracja, wolność, niepodległość, suwerenność. Technika ta nie jest zła sama w sobie, a jej głównym celem jest jednoczenie społeczeństwa wokół wspólnych wartości. Niemniej jednak może być nadużywana przez polityków na potrzeby walki politycznej i wygrania wyborów ${ }^{40}$.

Technika mniejszego zła (ang. lesser of two evils) polega na przekonaniu odbiorców, że spośród wielu złych rozwiązań jedno jest najlepsze i powinno być zaakceptowane przez społeczeństwo. Stosowana jest najczęściej w czasie wojny, w celu przekonania obywateli o potrzebie poświęcenia i poniesienia niezbędnych dla zwycięstwa ofiar. W czasie pokoju jej przekaz nie jest już taki jednoznaczny, a główny nacisk ukierunkowany jest na przekonanie społeczeństwa do przeprowadzenia niezbędnych kosztownych społecznie reform, na przykład reformy emerytalnej. Ponadto często winą za wszelkie trudy i wyrzeczenia obarczany jest wrogi kraj (w czasie wojny) lub wroga grupa polityczna (w czasie pokoju). Prezentowana idea jest zwykle przedstawiana jako jedyna opcja lub jako rozwiązanie, które należy wybrać dlatego, że każde inne jest gorsze. W konfrontacji z tą techniką podmiot, na który jest ona ukierunkowana, powinien brać pod rozwage wszystkie możliwe rozwiązania stojących przed nim problemów, a nie tylko zaproponowane w przekazie propagandowym.

Doczepianie ogólników (ang. name calling) występuje często w scenariuszach politycznych i wojennych, ale bardzo rzadko w reklamie. Jest to użycie obraźliwego języka lub słów, które niosą negatywną konotację

\footnotetext{
39 Tamże, s. 244.

40 Tamże, s. 242.
} 
przy opisie przeciwnika politycznego czy też militarnego. Propagandyści usiłują wzbudzić wśród opinii publicznej uprzedzenie do wybranej grupy, nadając przeciwnikowi taką nazwę, która źle się kojarzy społeczeństwu lub której nie lubi. Często nazwę taką nadaje się za pomocą sarkazmu i ośmieszania, stosując określenia typu złodzieje, komuniści, faszyści, zdrajcy. Identyfikacja tej techniki polega na oddzieleniu emocji od odbieranego przekazu informacyjnego i poszukiwaniu merytorycznych przesłanek.

Wskazywanie wroga (ang. pinpointing the enemy) jest techniką wykorzystywaną zarówno w czasie wojny, jak również w kampaniach politycznych i debatach społecznych. Jest to działanie ukierunkowane na przedstawienie jednej konkretnej osoby lub grupy jako wroga społeczeństwa, narodu. Identyfikacja tej techniki propagandy polega na postrzeganiu przekazu informacyjnego i kierowanych w nim oskarżeń w kategoriach jednoznacznego dobra i zła. Do tego niezbędna jest analiza wszystkich dostępnych informacji na ten temat $\mathrm{i}$ ich odniesienia do uniwersalnego systemu wartości. Społeczeństwo dobrze wyedukowane i świadome otaczającej rzeczywistości, mechanizmów zachodzących w jego otoczeniu, jest o wiele mniej podatne na tego rodzaju propagandę.

Ludowość (ang. plain folks) to technika propagandowa, która ma na celu przekonać opinię publiczną, że poglądy propagandysty odzwierciedlają poglądy zwykłego, prostego ludu i z tego też względu działają również na korzyść prostych ludzi. Propagandysta często stosuje akcent i charakterystyczne zwroty określonej grupy odbiorców, wspierając przekaz żartami, gestami i zachowaniami. Dodatkowo podczas wystąpień język użyty przez propagandystę tworzy iluzję niedoskonałości mówcy poprzez błędy wymowy, jąkanie się i ograniczone słownictwo, co sugeruje jego szczerość, spontaniczność i swojskość. Technika ta występuje często w połączeniu z techniką błyskotek, przez co wzmacniany jest przekaz, a główny nacisk kładziony jest na wspólne wartości. W zderzeniu z tą techniką propagandy najlepszym sposobem jej przeciwdziałania jest oddzielenie idei prezentowanych przez propagandystę od jego osobowości i wyuczonych technik wystąpień publicznych.

Uproszczenie (ang. simplification) jest w swej istocie zbieżne $\mathrm{z}$ techniką wskazywania wroga, ponieważ często redukuje złożoną sytuację do wyraźnego wyboru pomiędzy dobrem a złem. Technika ta jest wykorzystywana w manipulowaniu niewykształconymi odbiorcami, postrzegającymi świat przez pryzmat ulubionych kanałów informacyjnych i powielającymi otrzymane przekazy informacyjne w bezrefleksyjny sposób. Jest taka rzeczywistość a nie inna, bo tak mówili w telewizji lub tak wyczytałem 
$\mathrm{w}$ Internecie. $\mathrm{W}$ walce $\mathrm{z}$ uproszczeniem niezbędne jest zbadanie innych występujących czynników i przekazów, czyli, podobnie jak w przypadku wszystkich innych technik propagandy, uzyskanie dodatkowych informacji z różnych kanałów komunikacyjnych ${ }^{41}$.

Referencja (ang. testionials) to technika wykorzystywana często w trakcie kampanii reklamowych i politycznych polegająca na odniesieniu się, w kontekście propagandy lub poza jej kontekstem, do cytatów lub rekomendacji, które próbują połączyć znaną lub szanowaną osobę z produktem, przedmiotem lub ideą. To nic innego jak odniesienie się do autorytetów (lub pseudoautorytetów, choćby celebrytów, a także fałszywych autorytetów będących na przykład agentami wpływu lub przywódcami partii politycznych) i przekonanie odbiorców, że jeżeli „autorytet” ma takie poglądy, to oni powinni mieć takie same, bez względu na fakty, koszty i okoliczności. Nie trzeba nic uzasadniać, autorytet przecież wie lepiej, co jest dobre, a co złe. Przeciwdziałanie tej technice propagandy polega głównie na obiektywnej ocenie wszystkich wad i zalet przedmiotu, oferty czy idei i wyciągnięciu bezstronnych wniosków, niepodyktowanych żadnymi subiektywnymi względami lub zewnętrznymi naciskami.

Ostatnią z wymienionych technik propagandy, stosowaną zarówno w polityce jak i podczas wojny, jest przenoszenie (ang. transfer). Polega na próbie stworzenia i przeniesienia autorytetu z jednej rzeczy czy téz osoby (grupy społecznej) na inną rzecz czy osobę (grupę społeczną) w celu zdobycia przychylności. Istotnego znaczenia nabiera wykorzystanie symboli, które niosą za sobą konkretne znaczenie. Stąd też politycy chętnie robią sobie zdjęcia na tle flagi narodowej, zyskując poparcie w propatriotycznej części społeczeństwa. W innym przypadku popierają palenie flag instytucji międzynarodowych, na przykład Unii Europejskiej, zyskując poparcie wśród eurosceptyków i narodowców. To także robienie zdjęć z osobami będącymi autorytetami, na przykład z Lechem Wałęsą w trakcie wyborów w 1989 roku czy też z papieżem. Technika transferu jest także wykorzystywana w budowaniu negatywnego postrzegania organizacji poprzez doklejanie im łatek związanych z ideologią, która w danym społeczeństwie kojarzy się w sposób jednoznacznie negatywny, jak faszyzm czy komunizm.

Następnym elementem związanym z propagandą jest sposób jej identyfikowania. Jest to proces złożony, wymagający wnikliwych i długotrwałych badań historycznych, ponieważ tylko w ten sposób można zidentyfikować jej kontekst i prawdziwy cel zastosowania. Podejście to

41 H.T. Conserva, Propaganda..., s. 74-76. 
wymaga badania wszystkich przekazów propagandowych, we wszystkich kanałach komunikacyjnych, reakcji jej odbiorców, zastosowanych technik i narzędzi, w długim przedziale czasu. Badanie efektów propagandy w krótkim przedziale czasu może być zasadne tylko w analizie propagandy taktycznej, wykorzystywanej na potrzeby doraźnych, taktycznych celów, na przykład kampanii wyborczej. Propaganda bazuje najczęściej na zakorzenionych w danej społeczności i kulturze tradycjach, mitach i stereotypach, co powoduje, że odróżnienie tego, co jest propagandą od tego, co nią nie jest, stanowi bardzo trudne zadanie, tym bardziej w krótkim przedziale czasu. Jak wspomniano wcześniej, propaganda jest działalnością celową, często prowadzoną przez lata i poszukując tego celu należy ukierunkować badania na długi przedział czasowy.

W cytowanej książce Propaganda and Persuasion przedstawiono 10-etapową procedurę analizy najważniejszych elementów propagandy. Jak podkreślają autorzy, jej wykorzystanie w analizie aktualnie prowadzonej propagandy jest złożone ze względu na nie do końca zidentyfikowany cel jej prowadzenia przy jednoczesnym braku danych do oceny jej skuteczności. Z drugiej jednak strony analiza bieżącej propagandy pozwala na zaobserwowanie sposobów wykorzystania mediów i bieżącej reakcji jej odbiorców. Poszczególne etapy analizy propagandy dotyczą następujących kategorii ${ }^{42}$ :

1. ideologia i cel kampanii propagandowej (ang. the ideology and purpose of the propaganda campaign);

2. kontekst, w którym propaganda jest wykorzystywana (ang. the context in which the propaganda occurs);

3. identyfikacja propagandystów (ang. identification of the propagandist);

4. struktura organizacji propagandowej (ang. the structure of the propaganda organization);

5. odbiorcy (ang. the target audience);

6. techniki wykorzystania mediów (ang. media utilization techniques);

7. techniki specjalne do zwiększenia efektu (ang. special techniques to maximize effect);

8. reakcja odbiorców na poszczególne techniki propagandy (ang. audience reaction to various techniques);

9. przeciwpropaganda, jeżeli występuje (ang. counterpropaganda, if present);

10. efekty propagandy i jej ocena (ang. effects and evaluation).

42 G.S. Jowert, V.O’Donnell, Propaganda and..., s. 290. 
Powyższy schemat poddano szczegółowemu opisowi w rozdziale szóstym How to analyze propaganda przywołanej książki. Szczegółowa analiza zawartych tam zapisów jednoznacznie uwidacznia, że kampania propagandowa jest skomplikowanym procesem, bazującym na istniejącej w danym społeczeństwie ideologii w odniesieniu do specyfiki czasów, w których jest realizowana. Dysponuje ona odpowiednimi strukturami organizacyjnymi wspierającymi propagandystów w dotarciu do określonych grup odbiorców. Wykorzystywane są w niej wszystkie możliwe media społecznego przekazu, najlepiej znajdujące się w rękach propagandystów, wsparte narzędziami zwiększającymi efekty oddziaływania, takimi jak na przykład wymienione wcześniej techniki propagandy. Ich dobór podyktowany jest specyfiką grupy docelowej oddziaływania informacyjnego i jej reakcją na stosowane techniki. Należy pamiętać także o tym, że zgodnie z prawem akcji i reakcji będziemy mieli do czynienia z przeciwpropagandą, czego najczęstszym przejawem w naszym codziennym życiu jest walka polityczna obozu rządzącego z opozycją i odwrotnie. Skuteczna propaganda wymaga także wyciągania wniosków z przeszłości. Analiza przeszłych kampanii propagandowych pozwala zidentyfikować, które z metod i narzędzi były skuteczne, w jakim środowisku społecznym propaganda była realizowana, w jakim czasie i jakimi kanałami komunikacyjnymi odbywał się przekaz i co należy zmienić w przyszłości, aby zmaksymalizować przekaz i tym samym skuteczność propagandy.

\section{Podsumowanie}

Propaganda we współczesnym społeczeństwie jest coraz powszechniej wykorzystywana do realizacji celów politycznych czy też nawet interesów narodowych. Jej rozwój związany jest bezpośrednio z rozwojem ludzkości, a zwłaszcza z wykorzystywanymi kanałami komunikacyjnymi. W czasach starożytnych i we wczesnym średniowieczu jej zasięg był mocno ograniczony, tak jak ograniczone były środki przekazu. Wraz z rozwojem społecznym propaganda zyskiwała na znaczeniu i stała się skutecznym narzędziem wpływu. Można zidentyfikować kilka głównych punktów przełomowych w rozwoju ludzkości, które miały wpływ na skuteczność i zasięg propagandy. Zawsze były związane z rozwojem technicznym i nowymi wynalazkami, takimi jak: druk, telegraf, telefon, radio, telewizja, sieć Internet. Co przyniesie przyszłość - zobaczymy. Najprawdopodobniej będzie związana z elementami sztucznej inteligencji zdolnymi do samodzielnego kreowania przekazów informacyjnych. 
Autor zdaje sobie sprawę z tego, że problematyka propagandy we współczesnym społeczeństwie jest bardzo skomplikowana i niejednorodna. Często trudno odróżnić, co jest propagandą, a co nią nie jest. Tym bardziej, że Internet, a zwłaszcza portale społecznościowe, są doskonałym środowiskiem propagandy ukierunkowanej na indywidualne preferencje jej użytkowników, często noszącej znamiona czarnej propagandy, współcześnie określane jako fake news. Jesteśmy zalewani informacjami z wielu źródeł i to, czy uznamy je za prawdziwe, zależy tylko i wyłącznie od nas. A do tego potrzebne są kompetencje, świadomość i wiedza. Paradoksem współczesnych czasów jest to, że mówimy o społeczeństwie informacyjnym, w którym de facto wiedza, jaką posiada rzeczone społeczeństwo, ma najmniejsze znaczenie. Nie mówimy tutaj o podmiotach takich jak państwa, instytucje międzynarodowe czy też korporacje. Dla nich wiedza jest niezbędna dla skutecznego działania. Ale te działania są tym skuteczniejsze, im uboższy jest intelektualny poziom środowiska oddziaływania.

Osobnym zagadnieniem, a raczej problemem i wyzwaniem, jest zjawisko konfliktu hybrydowego (wojny hybrydowej), w którym podmioty prawa międzynarodowego, ale nie tylko, wykorzystują informację jako narzędzie oddziaływania na obiekt, którym jest społeczeństwo, w celu realizacji przyjętych celów politycznych. Podyktowane to jest oczywiście pragmatyką związaną z redukcją kosztów prowadzenia konfliktu (wojny), zarówno w wymiarze ekonomicznym, jak również społecznym. Konflikt bowiem musi się opłacać i być społecznie akceptowalny. W tym obszarze propaganda będzie nabierała coraz większego znaczenia.

\section{STRESZCZENIE}

W artykule przedstawiono najważniejsze elementy propagandy wykorzystywanej jako narzędzie kreowania postaw w społeczeństwie. Zidentyfikowano środowiskowe uwarunkowania informacji oraz przedstawiono zakres odpowiedzialności bezpieczeństwa informacyjnego, uwzględniając takie obszary, jak bezpieczeństwo informacji, walkę informacyjną, dezinformację. Główny nacisk położono na zidentyfikowanie elementów składowych propagandy, schematu, według którego jest ona realizowana, oraz jej uwarunkowań społeczno-historycznych i kulturowych. Przedstawiono najważniejsze techniki manipulacji stosowane w propagandzie, a także sposób identyfikowania kampanii propagandowych. 
Piotr Dela

\section{Elements of Propaganda in Public Life}

The chapter presents the most important element of propaganda used as a tool to create attitudes in society. The environmental determinants of information were identified and the scope of information security responsibilities was presented, taking into account such areas as information security, information warfare, disinformation. The main focus was on identifying the components of propaganda, the scheme by which it is implemented, and its socio- historical and cultural determinants. The most important techniques of manipulation used in propaganda as well as the way of identifying propaganda campaigns are presented.

KEY WORDS: propaganda, disinformation, information security

\section{Bibliografia}

Bączek P., Zagrożenia informacyjne a bezpieczeństwo państwa polskiego, Torun 2006.

Chorobiński A., Walka informacyjna jako fundamentalny składnik działalności terrorystycznej $w$ przyszłości, http://konkursy.byd.pl/userfiles/files/chorobinski.pdf (dostęp: 22.12.2018).

Ciborowski L., Walka informacyjna, Torun 1999.

Conserva H.T., Propaganda Techniques, Bloomington 2003.

Gibson W., Neuromancer, przekł. P. Cholewa, Katowice 2009.

Godston R., Wirtz J.J., Strategic Denial and Deception. The Twenty-First Century Challenge, Waszyngton 2012.

Jowert G.S., O’Donnell V., Propaganda and Persuasion, Waszyngton 2006.

Kwećka R., Strategia bezpieczeństwa informacyjnego państwa, Warszawa 2014.

Ottis R., Lorents P., Cyberspace: Definition and Implications, Tallin 2010.

Volkoff V., Psychosocjotechnika, dezinformacja - oręż wojny, przekł. A. Arciuch, Warszawa 1999.

Wasilewski J., Zarys definicji cyberprzestrzeni, „Przegląd Bezpieczeństwa Wewnętrznego” 2013, nr 9. 